ISSN No. 0974-035X

An Indexed, Refereed \& Peer Reviewed Journal of Higher Education

Towards Excellence

UGC-HUMAN RESOURCE DEVELOPMENT CENTRE,

GUJARAT UNIVERSITY, AHMEDABAD, INDIA

\title{
EFFECT OF MINING ON THE ENVIRONMENT OF THE GREAT THAR DESERT
}

\section{Dr. Kshetrapal Singh \\ Dr. Om Prakash}

The Thar Desert extends between the Aravalli Hills in the north-east, the Great Rann of Kutch along the coast and the alluvial plains of the Indus River in the west and north-west. The "Thar" has rich mineral resources. The peninsular plateau is rich in minerals and forests and marked off the plains by a mass of mountain, flanked by the Eastern and Western Ghats.

\section{MINING IN INDIAN DESERT}

Western India is pre-eminent in quarrying and mining in India. The area is the second largest source of cement in India. It has rich salt deposits at Rann of katcha (Gujarat) and Sambhar (Rajasthan). Jodhpur sandstone is mostly used in monuments, important buildings, residential buildings, and such. This stone is termed "Chittarpatthar". Jodhpur has also got mines of red stone locally known as Ghatupatthar used in construction. ${ }^{1}$ Jalore, another place of Indian Desert, is biggest center of granite processing units.

Most of the part of the Great Indian Desert comes within the territory of State of Rajasthan. The Thar Desert is not destitute of mineral wealth. The area falling to the east of the Desert range exposes Precambrian rocks belonging to the Banded Gneissic Complex, Systems which are a store house of a variety of economic minerals such as Copper, Iron, Manganese, Bauxite, Nickel, Cobalt, Manganese, Limestone, Marble, Asbestos, Clay, Silica sand, Graphite, Mica etc. In India this area is the main producer of a few minerals like Lead \& Zinc, Emerald, Garnet, Wollastonite, etc. ${ }^{2}$

\footnotetext{
1 Gupta, Mohan Lal (2008) : Rajasthan Jyankosh, Rajasthani Granthagar, Jodhpur, ISBN 81-86103-05-8, Page No. 125

2 Proc. Indian Natn. (1978) Sci. Acad. Vol. 44 Part B No. 6 Page No. 437-440.
} 
Lignite coal deposits are there at places Giral, Kapuradi, Jalipa, Bhadka in Barmer district; Plana, Gudha, Bithnok, Barsinghpur, MandlaCharan, RaneriHadla in Bikaner district and Kasnau, Merta, Lunsar etc., in Nagaur district. Lignite based Thermal power plant has been established at Giral in Barmer district. ${ }^{3}$ "Neweli Lignite Barsinghpur Project" is in progress to establish two thermal power units of capacity 125 megawatts each at Barsinghpur in Bikaner district. Reliance Energy is working on establishing power generation through underground gasification technique in Barmer district with an outlay of about 30 billion rupees. ${ }^{4}$

There is large storage of good quality petroleum in Jaisalmer and Barmer districts. The main places with deposits of petroleum are Baghewal, Kalrewal, and Tawariwal in Jaisalmer district and GudhaMalani area in Barmer district. Barmer district has started petroleum production on commercial scale. ${ }^{5}$

Barmer district is in the news due to its large oil basin. The British exploration company Cairn Energy started production of Oil on a large scale. Mangala, Bhagyam and Aishwariya are the major oil fields in the district. This is India's biggest oil discovery in 22 years. This promises to transform the local economy, which has long suffered from the harshness of the desert. $^{6}$

There are over 3 million people working in mining production sector. In fact, mining in Rajasthan relies heavily on exploiting marginalized communities, $95 \%$ of the work force is Scheduled Castes or Tribal's, 3\% are women and another 15\% are children. This being largely an unorganized sector, unfair wages is the rule. Basic workers rights such as access to water and toilet facilities, social security, safe working conditions and compensation in the case of injury of accidental death does not exist.

In the wake of adverse climatic conditions and abysm rainfall mercifully, the state is endowed with rich mineral resources. Rajasthan is called a 'Museum of Minerals', next to Bihar. It possesses the widest range of mineral deposits which are as many as 33 in numbers. Non-ferrous and non-metallic minerals predominate in the state. Apart from metallic like Iron ore, Manganese, Copper, Lead, Zinc, Silver and Wolfram (Tungsten ore); there are over 28 different non-metallic minerals produced in the state and some of them are the largest source in

\footnotetext{
3 Arid Agriculture: State-of-the-Art Agro-Forestry vs. Deserts on the March. Brook \& Gaurav Bhagat 14 August 2003

4 Gupta, Mohan Lal (2008): Rajasthan Jyankosh, Rajasthani Granthagar, Jodhpur, ISBN 81-86103-05-8, Page No. 136

5 https://www .PlanningCommission.nic.in

6 https://www OilIndia.nic.in
} 
the country. The principal non-metallic minerals produced are Asbestos Barites, Bentonite, Calcite, Clay, Dolomite, Emerald, Feldspar, Fuller's earth, Garnet, Granite, Gypsum, Limestone, Marble, Mica, Quartz, Silica, Sand, Soapstone, Propylite, Pyrites and Vermiculate. ${ }^{7}$

Limestone mining is carried out in Kotputli, Sikar, Jodhpur, Nagaur (Goatn), Sirohi etc. These mining operations are opencast in nature. Khetri in Jhunjhunu district and Rajpura in Alwar are the areas where Copper mining takes place which is opencast as well as underground in nature.

Non-organized opencast mining like that of building stone, soap stone, mica, marble, felspar etc. Organized opencast mining would lead to more dusty operations than that of organized underground mining, but the problem of water pollution may be more significant in case of underground mining and would lead to problematic situations. The process of beneficiation again adds to water and air pollution. The most warning situation exists in case of nonorganized opencast mining, where no norms of Explosive Act or mining Regulation are applicable which give rise to multi-faceted environmental problem. The mining of building Stone Mica, Soap stone and Marble-ore is of great concern and is being extensively carried out in every part of the State.

\section{THE LEGISLATIVE FRAMEWORK FOR MINING SECTOR}

India's mineral and mining sector operates under a federal structure wherein the Central Government formulates the legislation for all minerals except the minor minerals and the State Governments formulate legislation for minerals classified as minor minerals. India has written legal and constitutional framework to manage the mineral sector. National Mineral Policy provides the direction for mineral sector. Management of mining sector is the responsibility of the Central Government and the State Governments. The Constitution bestows power to the Parliament to enact legislation relating to the mining and the States are bound by the Central legislation.

In the federal structure of India, the State Governments are the owners of minerals located within their respective boundaries. The Central Government is the owner of the minerals underlying the ocean within the territorial waters or the Exclusive Economic Zone of India.

7 Dhar, Bharat, B. (1990) Environmental Management of Mining Operation, Ashish Publishers, New Delhi, Page No. 352 
In this context, the entry at serial No. 23 of List II (State list) to the Constitution of India states, Regulation of mines and mineral development subject to the provisions of List I with respect to regulation and development under the control of the Union. The entry at serial No. 54 of List I (Central list) to the Constitution of India states, Regulation of mines and mineral development to the extent to which such regulation and development under the control of the Union is declared by Parliament by law to be expedient in the public interest.

In pursuance to the entry at serial No. 54 of List I, the Central Government have framed legislation titled Mines \& Minerals (Development and Regulation) (MMDR) Act, 1957 as Central Act for governing the Mineral Sector (other than Petroleum and Natural Gas) of the Country. The Mineral Concession Rules, 1960 and the Mineral Conservation and Development Rules, 1988 are the rules framed under MMDR, 1957 to develop and regulate mining sector.

The State Governments, as owners of onshore minerals, grant mineral concessions and collect royalty, dead rent and fees as per the provisions of MMDR Act, 1957. The MMDR Act, 1957 recognizes a substantial role for the State Governments. In exercise of powers under section 3 (e) of the MMDR Act, 1957, the central government notifies minor minerals. As per Section 15 of the MMDR Act, 1957 State Governments have complete powers for making rules for grant of concessions in respect of minor minerals; and levy and collection of royalty on minor minerals. In the case of major minerals, States substantially regulate and develop minerals subject to provisions of the Act. Further, as per section 23C of MMDR Act, 1957, State Governments have complete powers to make rules for prevention of illegal mining and for purposes connected therewith. Therefore, matters relating to regulation of mining and control of illegal mining of minor minerals are all matters which lie in the domain of State Governments.

The Central Government retains the power of revision, fixation of royalty etc. in respect of major minerals. The Ministry of Coal exercises all powers of the Central Government with respect to Coal and Lignite under the Act. The Department of Atomic Energy similarly exercises all powers for Atomic Minerals. In order to regulate the mining and development of minerals in the offshore area, the Parliament has enacted the "Offshore Areas Minerals (Development and Regulation) Act, 2002". The Act empowers the Central Government to grant mineral concessions for offshore areas and collect royalty. The Mines Ministry administers the OAMDR Act, 2002 and the rules made there under, for all minerals, other than Petroleum and 
Towards Excellence: An Indexed, Refereed \& Peer Reviewed Journal of Higher Education / Dr. Kshetrapal Singh \& Dr. Om Prakash / Page 52-60

Natural Gas within the territorial waters and the continental shelf. The Indian Bureau of Mines has been notified as the administrative authority for concession management of offshore areas.

\section{EFFECT OF MINING ON THAR DESERT}

Many people living in "The Thar Desert" lack basic access to healthcare services, water supplies and educational facilities. They are uninformed of their rights as individuals and lack the resources to change their situation for themselves and their families. This type of life means levels of unemployment, disease and infant and child mortality are all very high.

\section{MINING AND ECOLOGICAL ENVIRONMENT}

Many direct and indirect effects of mining can be seen in Ecological Environment of Thar Desert. Clearing of all vegetation from the land designated for opencast mining of soils and overburden constructions, Deforestation, removal of forests for clearing the land for mining, disturbances in the living of wild animals. Noise, vibrations, air water pollution, blocking of corridors, Retardation in the growth of plants, deposition of dust on leaves and presence of gasses, in the atmosphere, degradation of aquatic flora and fauna, Loss of agricultural products due to reduced availability of water, siltation over soils, acid mine drainage may also be seen due to water pollution as a result of discharge of effluents in surface water bodies.

\section{EFFECTS ON ECOLOGICAL SYSTEM}

\section{Ecological impacts of Opencast Mining}

In general the impacts of opencast mining on the ecology of mining and surrounding area are as outlined below.

a) Removal of all vegetation (flora) and thereby fauna from the area the area required for mining and other purposes.

b) Pollution of water in the surrounding water bodies due to leaching from overburden dumps and due to the pollutants from the other activities. This affects the aquatic ecology of these water bodies.

c) Dust in atmosphere, contributed by mining and associated activates. When deposited on the leaves of the plants in the surrounding areas may retard their growth. 
Towards Excellence: An Indexed, Refereed \& Peer Reviewed Journal of Higher Education / Dr. Kshetrapal Singh \& Dr. Om Prakash / Page 52-60

d) Noise and vibrations due to blasting and operation of the machines drive away the wild animals and birds from the nearby forests.

e) Water scarcity caused due to the impacts of opencast mining on water regime affects the growth of vegetation on agriculture in and around the complexes.

\section{Ecological impacts of underground mining}

The impacts of underground mining of minerals on ecology are:-

a) Clearing of area for developing shaft/incline complex, infrastructure, colonies, etc. may require removal of some vegetation and thereby driving away the fauna.

b) Water scarcity, caused due to the impacts of mining on water regime, along with pumping and release of polluted water on the surface may affect vegetation in the surrounding areas.

c) Top-soil I tensile zones of subsiding areas may lose its vegetation supporting capability. Release of polluted water from the underground mines into the surface water bodies may affect their aquatic ecology.

\section{IMPACTS ON ENVIRONMENT}

The mining and associated activities in the mining complexes not only pollute the air but also cause noise pollution. These are briefly given below.

\section{Impacts of opencast mining on the atmosphere}

Removal of vegetation from the area designated for mining and other purpose produces dust which when air-borne causes an increase in the concentration of SPM in the surrounding air. Removed handling, transportation and storage of soils also cause an increase in the concentration of SPM in the atmosphere. ${ }^{8}$ The use of Riesel equipment in these activities causes an increase in the level of No. Drilling and blasting of overburden and the mineral contribute SPM and explosive fumes into atmosphere. In-pit crushing, loading and transportation of the minerals and the overburden rock mass and making the dumps contribute

8 Saxena, Naresh Chandra And Other, (2013), Environmental Management In Mining Areas Scientific Publishere (India) Page No. 67 


\section{Kshetrapal Singh \& Dr. Om Prakash / Page 52-60}

SPM and No. Minerals and rock mass having sulphur and its compounds may contribute $\mathrm{SO}_{2}$. Making of the overburden dumps and the sue of diesel equipment for this purpose contributes SPM and No. Some of the sedimentary rocks may have $\mathrm{CH}_{4}$ and when mined they may contribute this gas to the surrounding air. Fires in opencast mines contribute heat; $\mathrm{SPM}, \mathrm{SO}_{2}$,

$\mathrm{CO}_{2}$ and $\mathrm{CO}$. Use of petrol and diesel vehicles in the mines contributes hydrocarbons and lead. The equipment used in the opencast mines for various purposes including the transport of the overburden and mineral generate continuous noise. While blasting it produces impulsive noise. All the noise generated in the mine does not become ambient noise generated from the different sources gets reflected and ultimately the resultant of all the noises after reflection and refraction reaches the surface to become the ambient noise.

\section{Impacts of underground mining on the atmosphere and noise regime}

The exhaust air from the underground mines contributes areas, e.g. diesel generating stations boilers etc. contribute $\mathrm{SPM}, \mathrm{CO}_{2}, \mathrm{CH}_{4}, \mathrm{NO}, \mathrm{SO}_{2}$ and other pollutants. The surface activities in the underground mining areas, e.g. diesel generating stations, boilers etc. contribute SPM, NO, and $\mathrm{CO}_{2}$. The machines and equipment installed at the shafts. Inclines and compressor houses workshops etc. generate noise which tends to become ambient noise as it is generated on the surface.

\section{Impacts of mineral preparation activities on the atmosphere}

Mineral handling, mineral preparation and associated activities mainly contribute SPM to the atmosphere. In mineral preparation plant having chemical processes producing gases the atmosphere may get polluted due to emission of the gases. The crushers conveyors and other equipment installed in the mineral handling and preparation plants produce continuous noise.

\section{Mine Gases and Blasting Fumes}

The air quality of mines sites can be considered as the polluted one due to the fact that the mining activity releases a number of pollutants in the atmosphere. Further in absence to sufficient ventilation. The air pollution level is very high in the underground mines and sublevels in certain mines. The mine gases and gases generated due to blasting processes are main pollutants of air in the mining areas. Carbon Monoxide, Carbon dioxide, Sulphur dioxide are found in coalmines as mine gases. The polymetallic mining also releases hazardous gases. 
Likewise, the explosives when blasted produce a large volume of hazardous gases like oxides of nitrogen $\left(\mathrm{NO}, \mathrm{NO}_{2}, \mathrm{~N}_{2} \mathrm{O}_{3}\right)$ and carbon monoxide, in underground mining it the ventilation is not proper, then these gases may remain there for a longer time.

In large scale mechanized mine, where the heavy machinery are used for loading and transportation purpose, several gases emitted by these diesel operated machines like $\mathrm{CO}$, hydrocarbons, $\mathrm{SO}_{2}, \mathrm{NO}_{2}$ hydrogen supplied and lead particles.

The nitrous fumes are physiologically very toxic. High NO2 does result in the nosal irritation, breathing discomfort, respiratory distress and eye irritation. The health hazards due to nitrous fumes vary with its concentration an period of exposure. The works who are engaged in sub surface drilling and blasting activities are more affected by the nitrous fumes toxicity.

The sulphur dioxide causes irritation effects and it may penetrate the respiratory tract and damages the small delicate cilia of the membrane. Prolonged exposure high $\mathrm{CO}_{2}$ and $\mathrm{CO}$ may create adverse effect on respiration system. Carbon monoxide is very dangerous to the health of the workers because it is combined with the hemoglobin in the blood to form carboxy hemoglobin and which restrict $\mathrm{s}$ the oxygen carrying capacity of hemoglobin. Acute intoxication is caused by exposure to high concentration of carbon monoxide and is manifested by headache, dizziness, loss of consciousness, etc. if exposure is long enough. The hydrocarbons cause eye, Nose and throat irritations.

\section{Conclusion}

To conclude, Mining impacts are generally confined to the area in which the mine operates, but off site impacts may occur, particularly in relation to water resources. Mining activities may also result in, or contribute to, cumulative impacts. Cumulative impacts refer to the combined incremental effects of human activity which may be insignificant in isolation, but accumulate over time from one or more sources, resulting in environmental degradation.

There are a range of environmental impacts associated with sand mining. "Thar Desert" where sand and various kinds of stone mining is occurring in a biologically diverse coastal area, these include a loss of biodiversity; an increased risk of invasion by weeds; an increased 
risk of acid sulphate soils; erosion and sedimentation as a result of changes to water flows; and groundwater drawdown which may impact on groundwater dependent ecosystems.

Once mining activities are complete, mined areas should be rehabilitated by the mining operators with adequate and assured resources to a functioning natural landscape approximating the pre-mined condition as far as is feasible. Rehabilitation planning should be

part of an integrated mining management program and refined and managed throughout the operational phase of the mine. Rehabilitation comprises developing designs for appropriate

landforms, creating landforms that will behave and evolve in a predictable manner, and returning appropriate and sustainable ecosystems.

Mining operations typically have a requirement for high volumes of fresh water for use in washing; filtering and other mining processes; haul road dust suppression; and consumption by workforce and community. Water may be sourced from on site runoff, or by operating bore fields into shallow aquifers underlying the area or deeper artesian aquifers. Important issues for mine sites include preserving water quality of local river ecosystems that may be linked to the shallow aquifers, and long term sustainability of deep aquifers that may be slow to recharge.

Noise, water and air pollution, including the release of greenhouse gases and airborne emissions are additional issues associated with mining activity. All of above processes have the under mentioned adverse impact on the existing balance of ecosystem and causes land of degradation

\section{Dr. Kshetrapal Singh \\ \& \\ Dr. Om Prakash}

